\title{
An Overview of Remote System for Geographical Information Decision Support in Paddy Plantation
}

\author{
Muhammad Faris bin Muhammad Eshammuddin, Mohd Hudzari Bin Haji Razali*, Che Ahamad Asyraf bin Che \\ Manan and Muhammad Husain bin Mohd Kasim
}

Faculty of Agrotechnology and Plantation, Universiti Teknologi MARA, Malaysia

Submission: April 05, 2019; Published: April 30, 2019

"Corresponding author: Mohd Hudzari Bin Haji Razali, Faculty of Agrotechnology and Plantation,Universiti Teknologi MARA (Melaka), Kampus Jasin, 77300, Melaka Bandaraya Bersejarah, Malaysia

\begin{abstract}
Agriculture is a concept of science and knowledge that being applied to solve the need of people for food requirement. Precision farming is a way of agricultural production that involve the latest technologies where the application of seed, fertilizer supply, spraying and others has taken place based on the situation on the field. The aim of these studies is to create a map to display the spatial data and it attributes data by using the ArcMap software to help in making a better decision making. Using ArcGIS can help the farmers know in field before do something at area. The geographic information system (GIS) created can help in generating different view on our field such as the water table, soil nutrient content, soil pH and other [1]. By using this software, readers know how to identify the plantation zone and the feature inside the plantation zone. This studied was done by locating a specific point at paddy field in Merlimau. The geographical coordinates of each location in this study were recorded by using this device signal from satellite-based Global Positioning System. The data was converting in the ArcMap software to be analyzed after being recorded by the GPS [1]. The article provides an overview of Application of GIS and GPS in field. The result showed all data of waypoint and track in map with different layer containing the attributes.
\end{abstract}

Keywords: ArcMap; ArcGIS; GPS; Precision agriculture

Abbreviations: GIS: Geographic Information System; PA: Precision Agriculture; DSS: Decision Support System; GPS: Global Positioning System

\section{Introduction}

In the past, agriculture practice in developing countries have been involve a large amount input in the form of mechanization and the application of fertilizer and pesticides to improve the productivity of the farm [2]. Although it have been prove to can help in increasing the productivity of the farm but with the current technologies such as the remote sensing being applied in real life situation [3], it can help in reducing the wastage of pesticide and fertilizer application as it can detect the area that needed the more concentration based on the degree of damage or lack of nutrient content in the soil that lead the crop to produce low yield [4]. Using the information given by the remote sensing we can give more attention to the place by giving more pesticide or fertilizer or vice versa toward that area to help improving the problem.

\section{Methodology}

Remote sensing is the collection of process that include several methods such as acquire, prepare and decipher the information that being receive in the form of spectral on an object without being direct in contact with the object that being studied [5]. Nowadays, the application of remote sensing without many people realize can be found in numerous applications including photography, surveying, geology, forestry and many more. However, the large discovery can be found in the agriculture sector. In agriculture, remote sensing can be used to forecast the expected crop production and yield over a given area and determine how much of the crop will be able to predict the quantity of crop that will be produced in a given period of time. The integration of these technologies into a single system that allow the user to monitor the farm at precise level consist of the characteristic, geology and exploration in lowland agriculture can help in increasing the success of precision farming. The importance of precision farming also can be seen when being use in mountainous terrain compare to flat agricultural site as we can see the status of the location whether it is suitable for farming or not because of several factor such as nutrient contents, landslides, soil composition and others. Therefore in order to manage the agriculture at such small site specific crop areas it becomes very important to actually identify the each field location.

Precision farming or precision agriculture (PA) is a technology available for sustainable agricultural production, which enables farm management based on small-scales spatial variability of soil and crop parameter in the field [6]. The aim of Precision 


\section{Agricultural Research \& Technology: Open Access Journal}

Agriculture is a better usage of resource and control mechanism so as to improve production efficiency, reduce input cost and environmental impact $[7,8]$. Mapping is the beginning in precision agriculture, yield and soil mapping are often the focus of PA ArcMAP Software (Figure 1-14) discussion and activity, therefore yield and soil mapping must be accurate in order to get true measurement of variability and to establish the guidelines for PA in particular farm field [9-12].

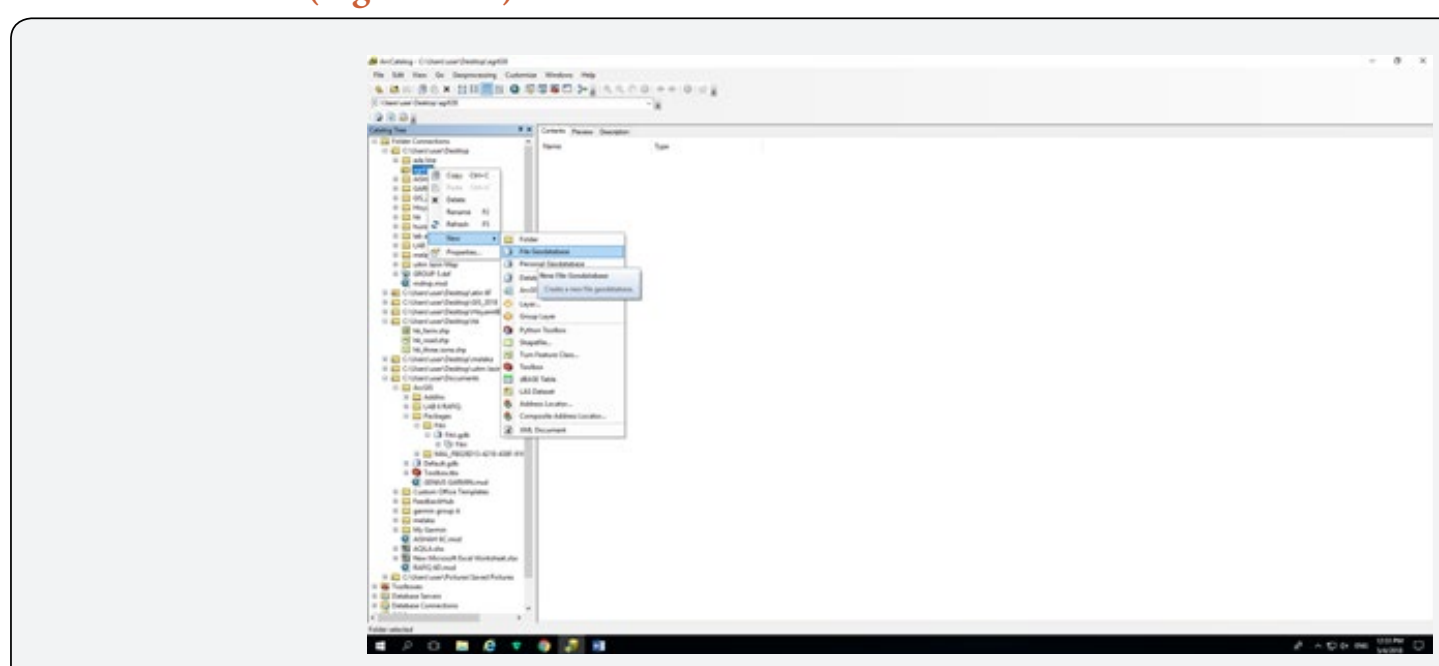

Figure 1: Create a folder at the desktop and open the ArcCatalog software. Select the file and click the geodatabase

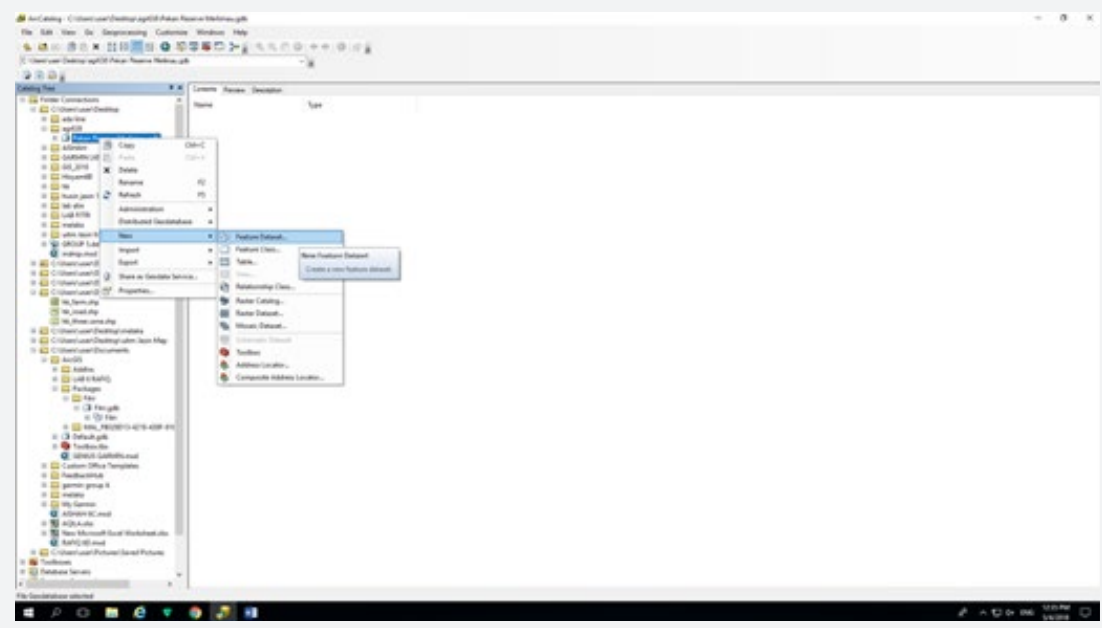

Figure 2: Click the geodatabase that being create and click the feature dataset.

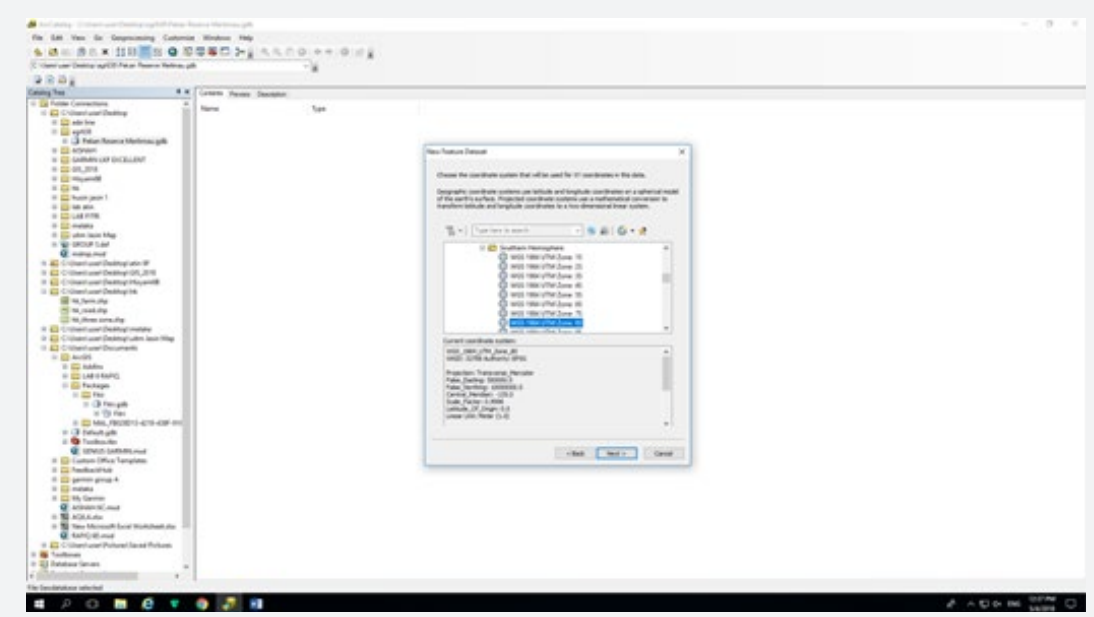

Figure 3: Create 3 type of feature dataset that consist of polygon, point and line feature and the coordinate is the same as below.

How to cite this article: Md Faris Md Eshammuddin, Mohd Hudzari B H R, Che Ahamad A bin C M, Muhammad Husain Mohd K. An Overview of Remote System for Geographical Information Decision Support in Paddy Plantation. Agri Res\& Tech: Open Access J. 2019; 21(2): 556162. DOI: 10.19080/ ARTOAJ.2019.21.556162 


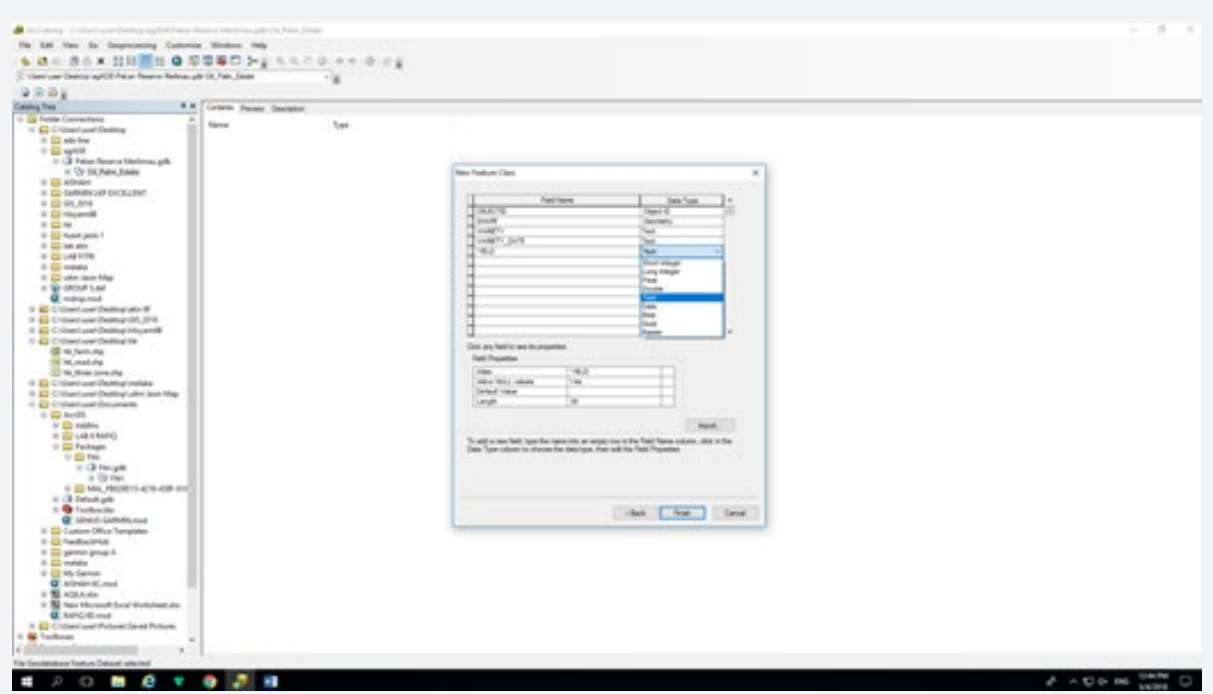

Figure 4: Set the name of the feature class for each of the dataset.

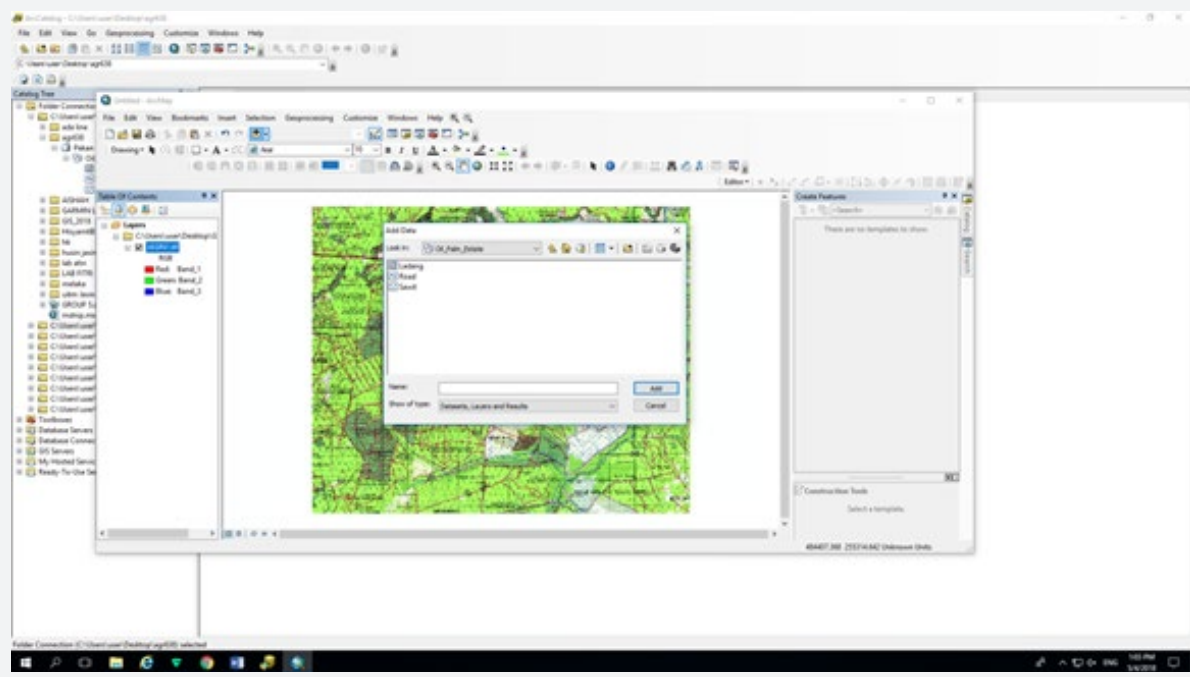

Figure 5: Add the data of Jasin into ArcMap software and add the data from the ArcCatalog.

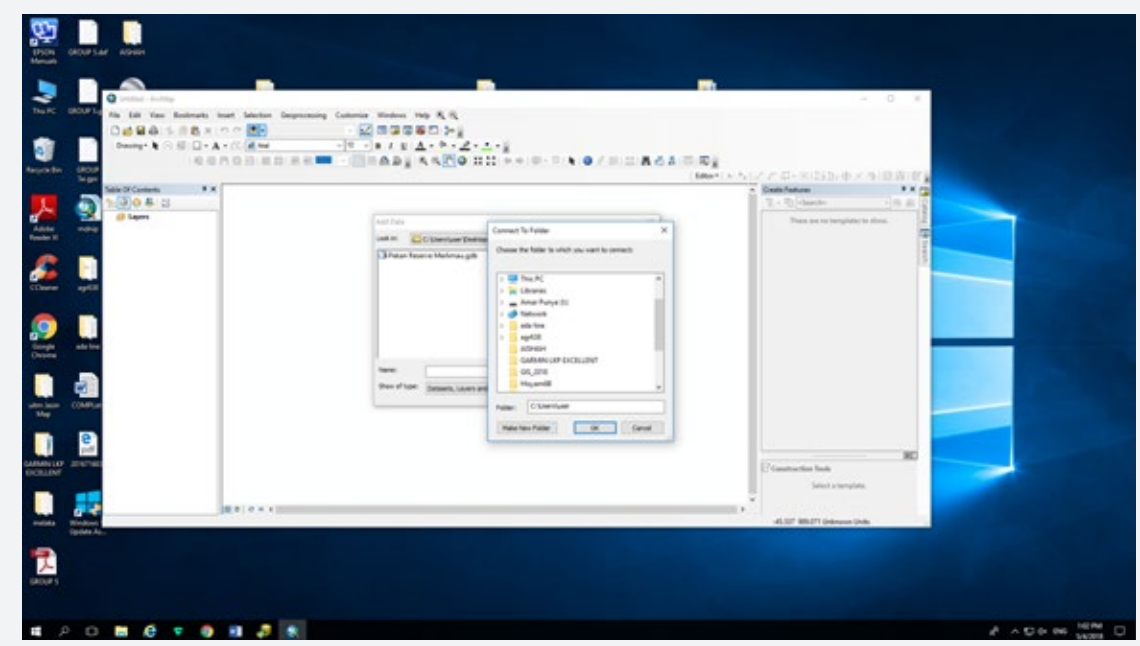

Figure 6: Connect the data of Paddy Field into the Agr638 file. 


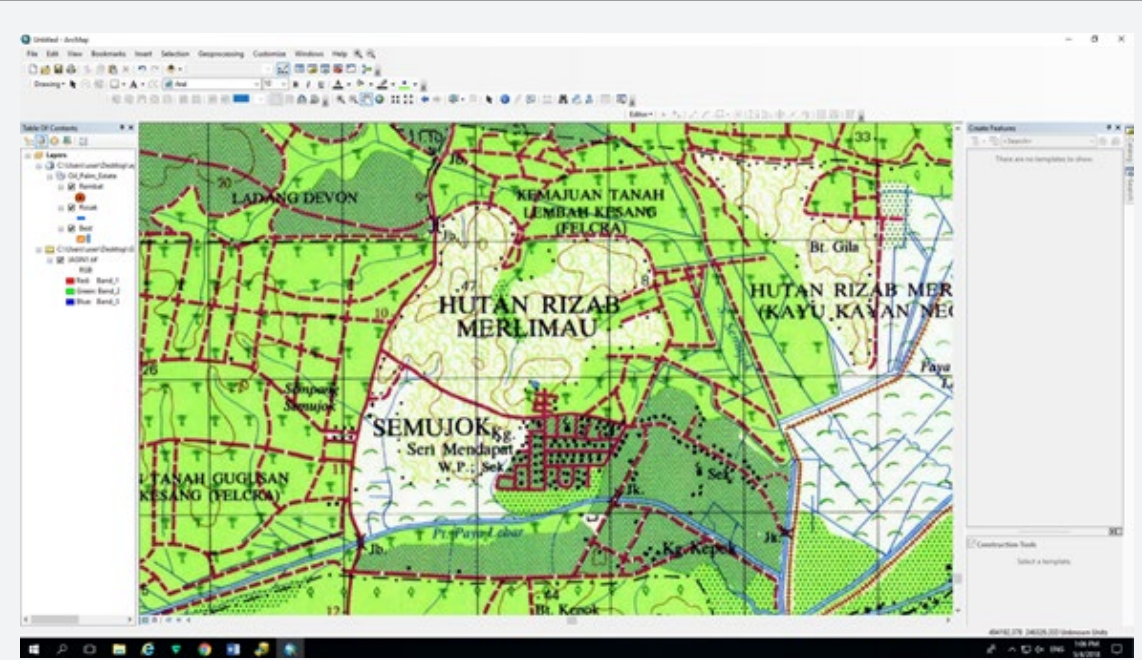

Figure 7: Data from the ArcCatalog will be display on Table of Content Layer.

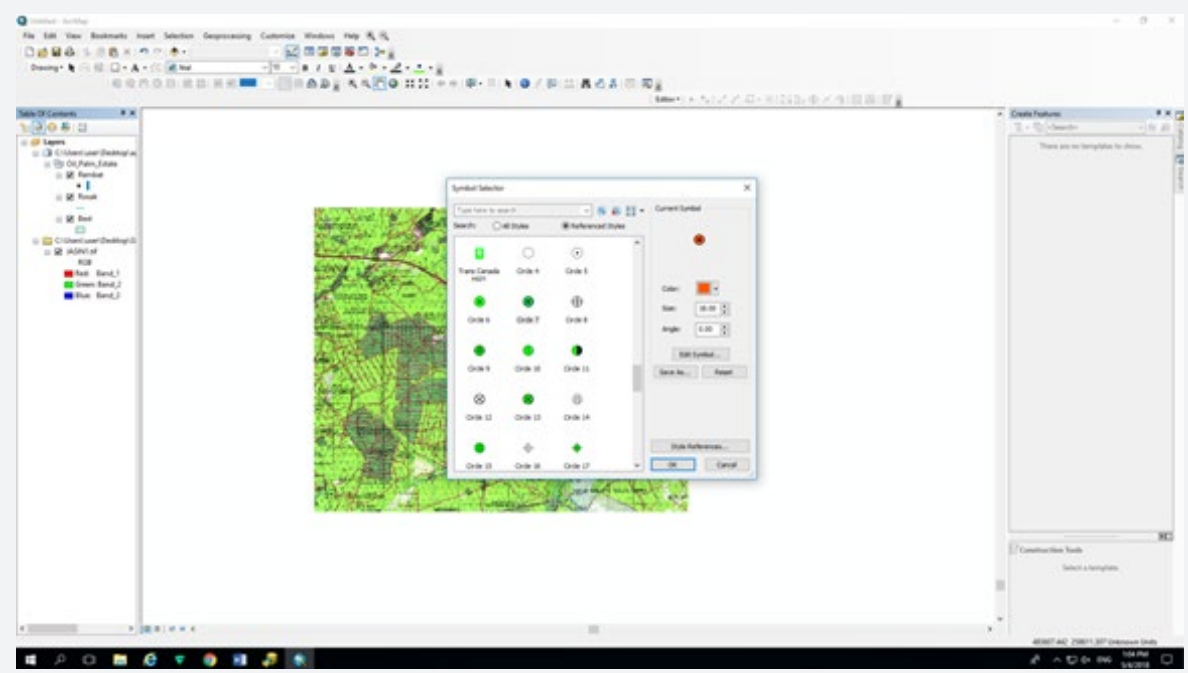

Figure 8: Add or change the symbol to aid the editing process.

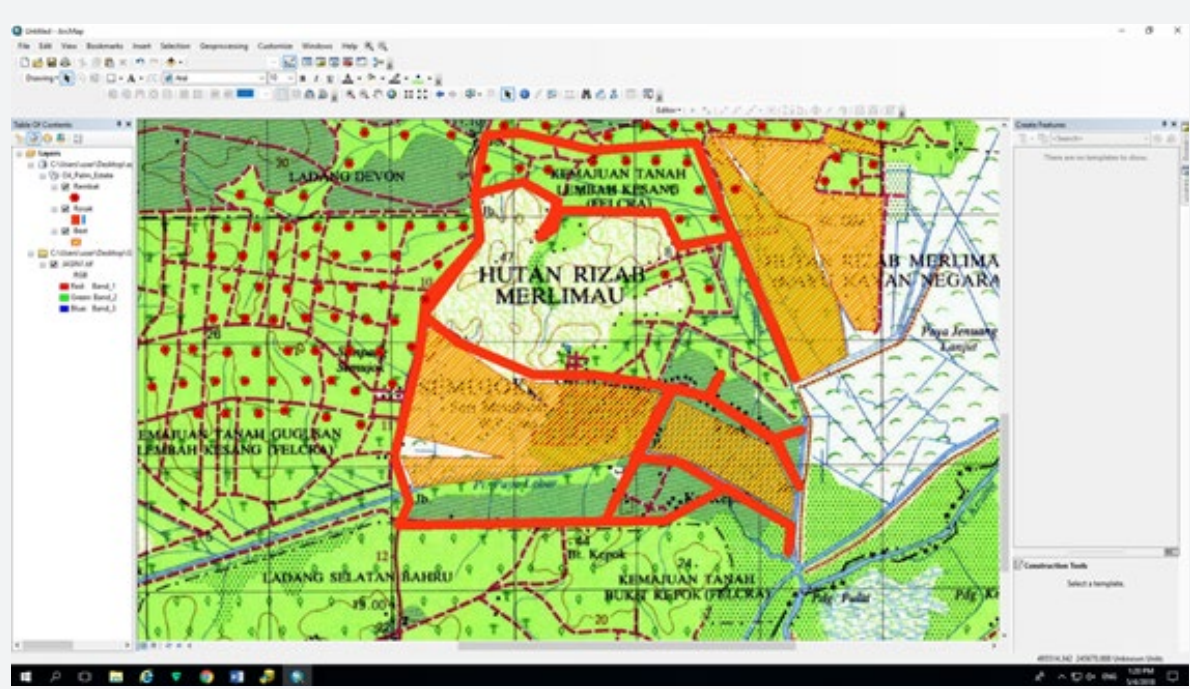

Figure 9: Editing the feature in the map based on the location of the planting point, building area and road. 


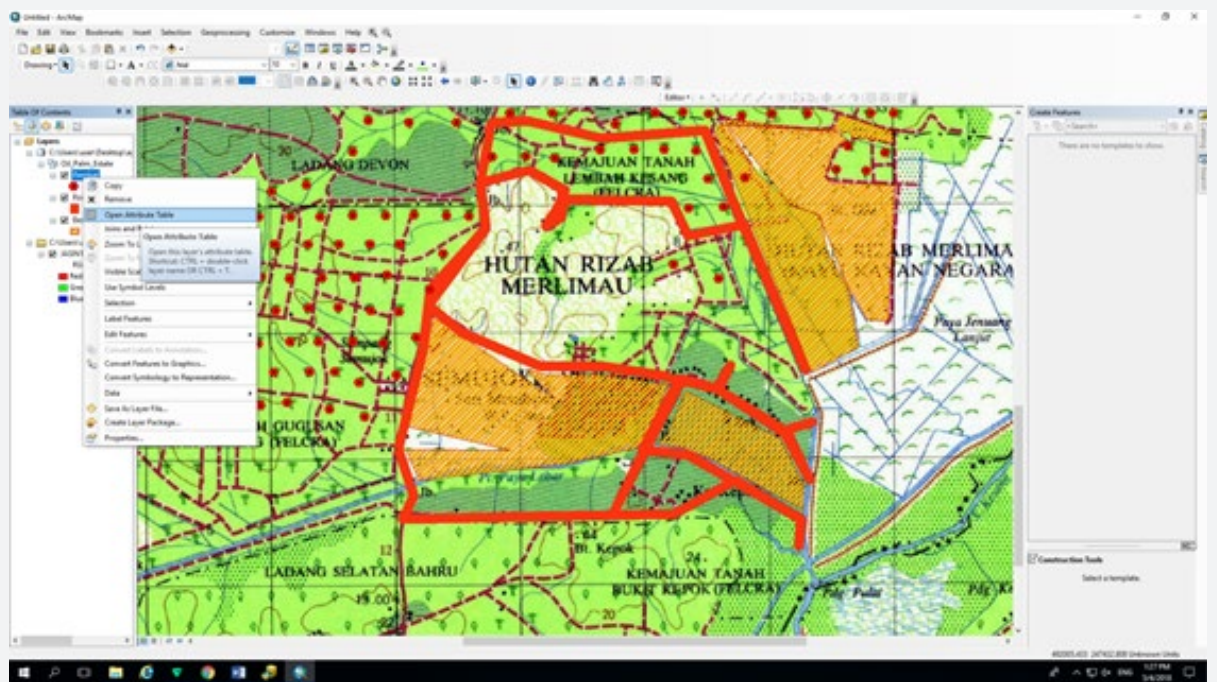

Figure 10: Open the attribute data to see record.

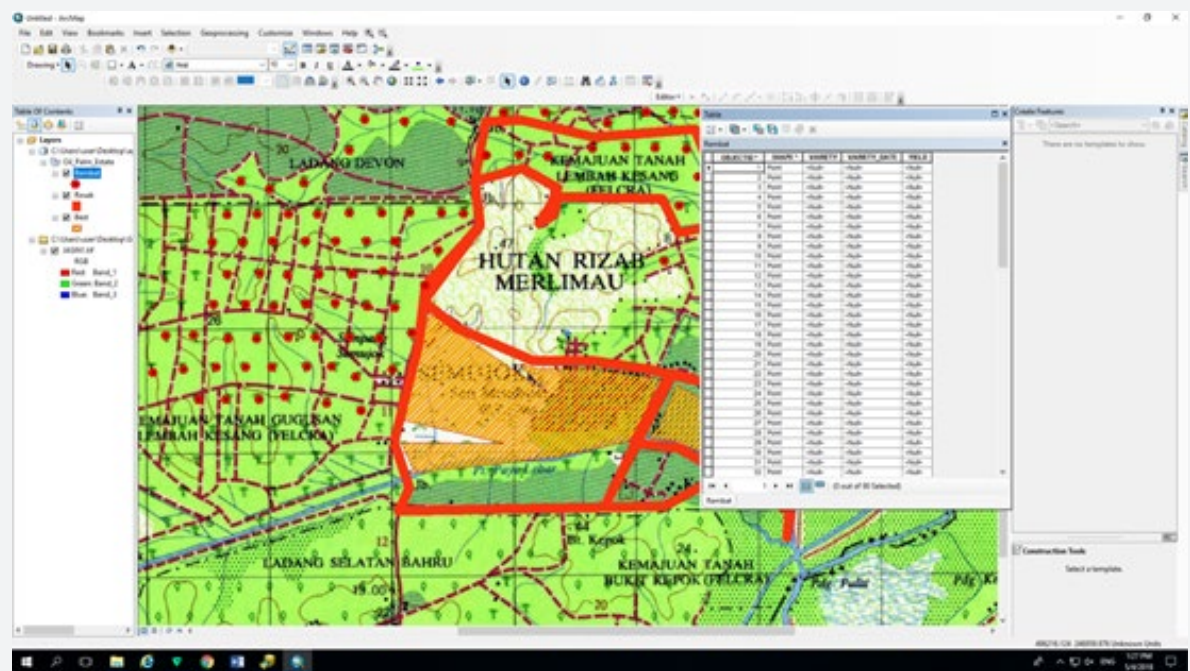

Figure 11: The table show the attribute of the planting point, road and building area.

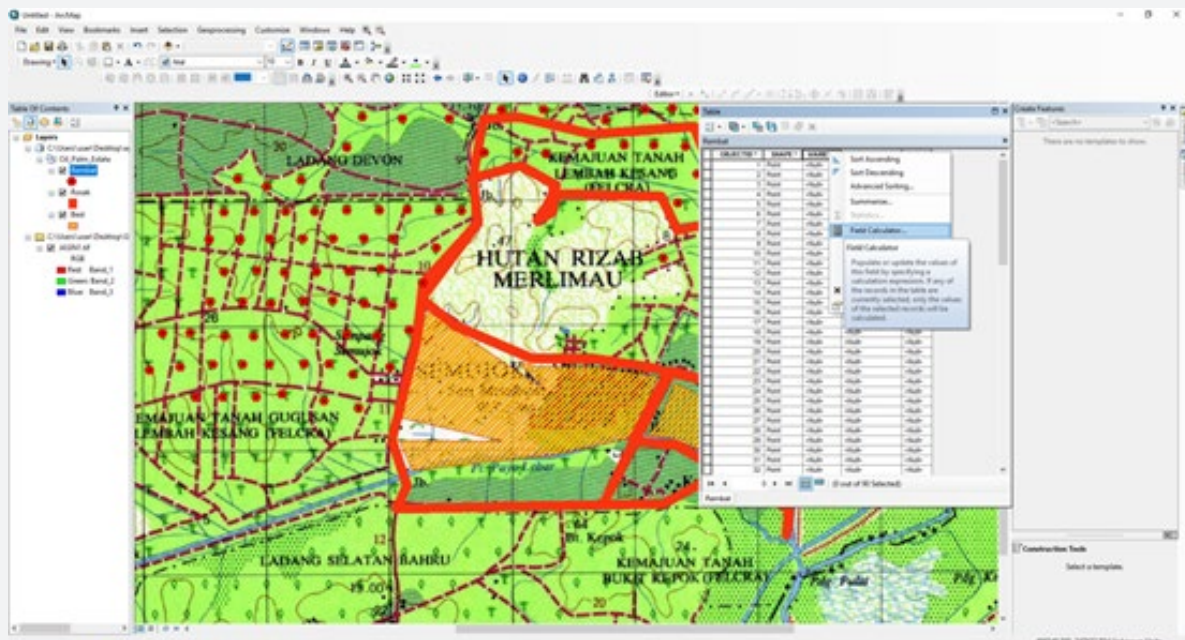

Figure 12: Open the field calculator to update the value in the field 


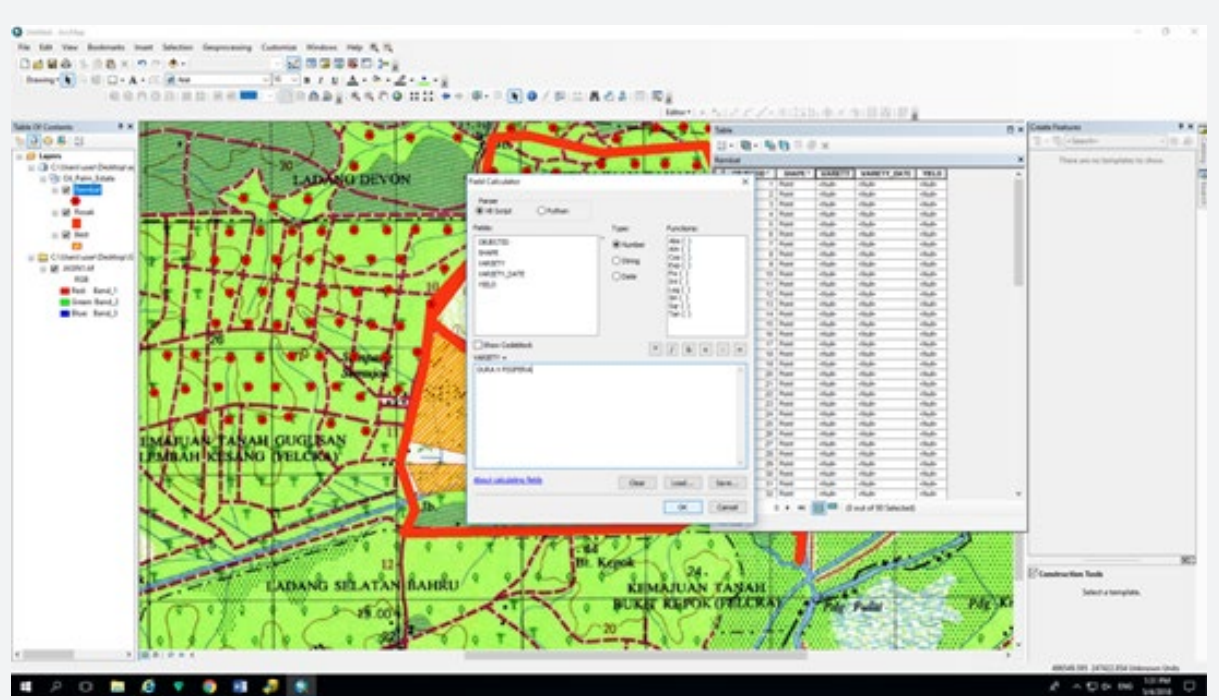

Figure 13: Edit the variety in the field calculator.

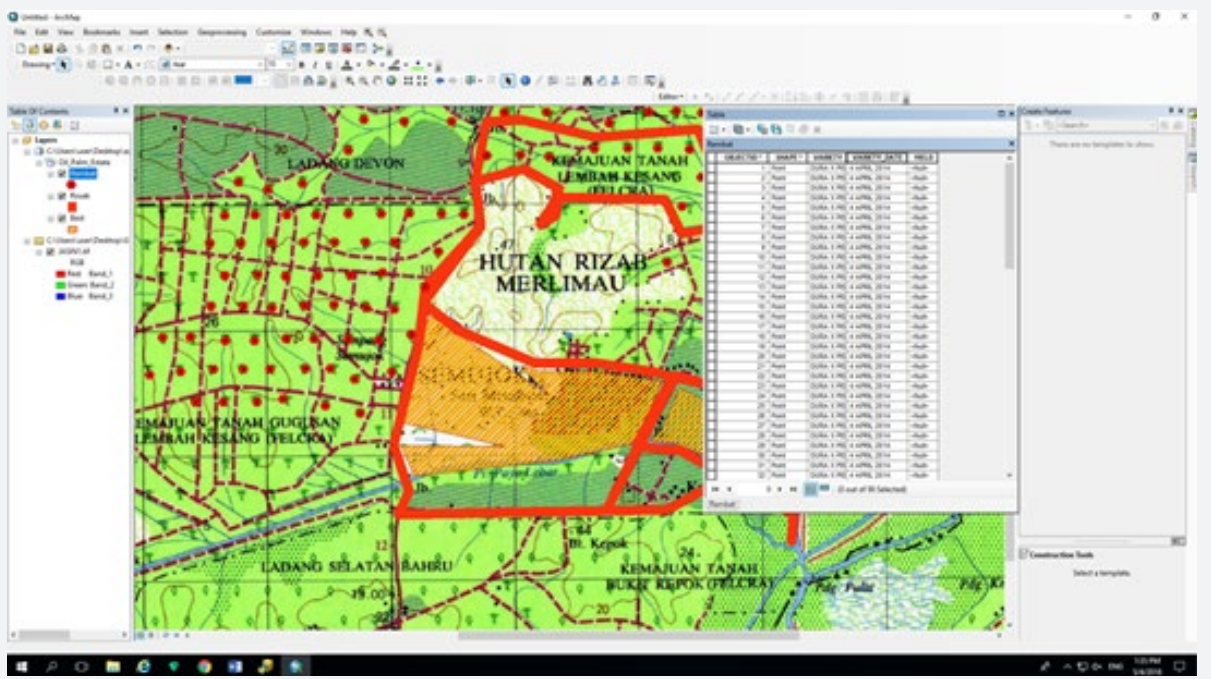

Figure 14: The attribute of the paddy field can be seen after the analysis been done.

\section{Conclusion}

In this modern day, the use of GIS and remote sensing have become the main solution that farmer use to solve their problem and it application have seen increasing every year varying from Decision Support system (DSS) on mapping, yield estimation, harvesting time, pest management and food security and safety. Nowadays, it becomes one of important technology that can share information and data online and based on real-time application compare to traditional stand-alone application. This advantage provides spatial data that can be used as references to millions of users. Thus, it can help public on making policy and making new strategy on precision farming.

\section{References}

1. Kamaruzaman Jusoff, Jamalludin Syam, Swapan Kumar Ray (2000) Precision Agriculture using Satellite Technology, Geographic Information System (GIS) and Global Position in System (GPS). UPM Research Report 1997-2000, Environmental Sciences. pp. 269-271.
2. Liaghat S, Balasundram SK (2010) A Review: The Role of Remote Sensing in Precision Agriculture. American Journal of Agricultural and Biological Sciences 5(1): 50-55.

3. Folhes MT, Renno CD, Soares JV (2009) Remote sensing for irrigation water management in the semiarid Northeast of Brazil. Agric Water Mgmt 96(10): 1398-1408.

4. Hinzman LD, Bauer ME, Daughtry CST (1986) Effects of nitrogen fertilization on growth and reflectance characteristics of winter wheat. Remote Sens Environ 19(1): 47-61.

5. Gandhi SM, Sarkar BC (2016) In Essentials of Mineral Exploration and Evaluation ( $1^{\text {st }}$ edn). Elsevier, pp. 410.

6. Haneklaus S, Kohrs K, Schmidt G, Schnug E (1997) Influence of Nitrogen Fertilization on Yield and Quality of Sugar Beet. Fertilization for Sustainable Plant Production and Soil Fertility 1: 203-207.

7. Costopoulu, Anagnostou (1997) Rural area networks for precision agriculture. Precision Agriculture 97: 861-868.

8. Lowenberg-Deboer (2003) Precision Farming or Convenience Agriculture, Australian Society of Agronomy. Solutions for a better environment. Proceedings of the $11^{\text {th }}$ Australian Agronomy Conference, $2-6$ Feb. 2003, Geelong, Victoria. p. 1-10. 
9. Schuller JK (2001) Variable rate technologies. Paper Smart Fanning II Workshop on Automation for Agriculture. PutraJaya, Malaysia.

10. Smith Katherine (2002) Does Off-Farm Work Hinderë Smartí Farming? USDA Agricultural Outlook, p. 28-30.

11. Fauzul Azhan Abdul Aziz, Abdul Rashid Mohamed Shariff, Mohd Amin bin Mohd Soom, Anuar Abdul Rahim, Ebrahim Jahanshiri, et al.

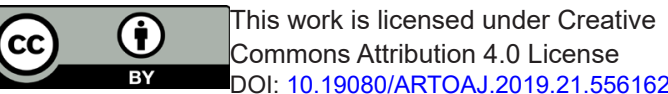

(2008) GIS based System for Paddy Precision Farming. IAALD AFITA WCCA2008 World Conference on Agricultural Information and IT, Tokyo, Japan. pp. 417-422.

12. (2001) Use of Remote Sensing and GIS technologies in Precision Farming for Rice Crop in Malaysia. Newsletter of the Malaysian Centre for Remote Sensing, (MACRES).

\section{Your next submission with Juniper Publishers will reach you the below assets}

- Quality Editorial service

- Swift Peer Review

- Reprints availability

- E-prints Service

- Manuscript Podcast for convenient understanding

- Global attainment for your research

- Manuscript accessibility in different formats

( Pdf, E-pub, Full Text, Audio)

- Unceasing customer service

Track the below URL for one-step submission https://juniperpublishers.com/online-submission.php 